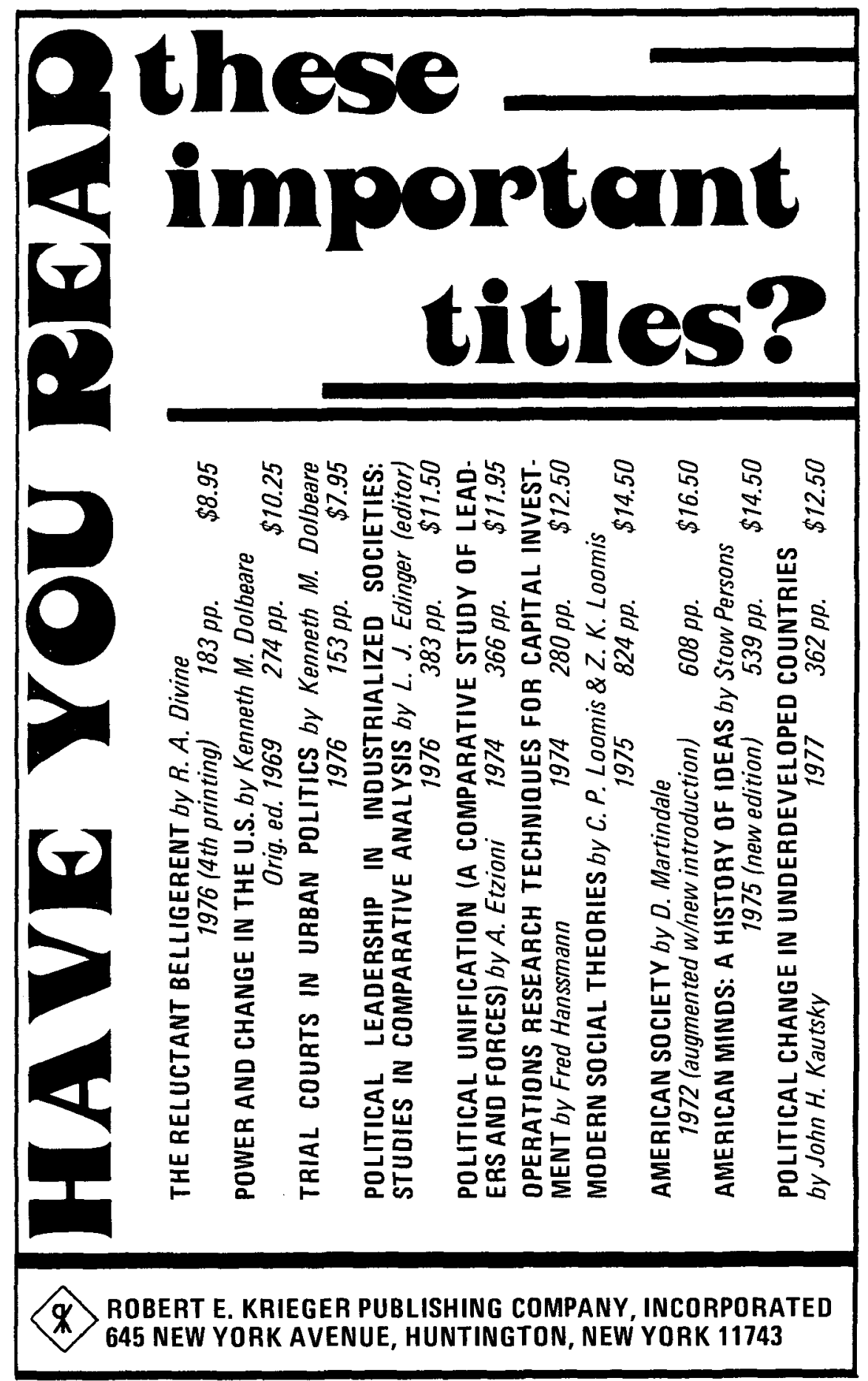




\title{
Climates of Hunger
}

MANKIND AND THE WORLD'S CHANGING WEATHER

\author{
Reid A. Bryson and Thomas J. Murray
}

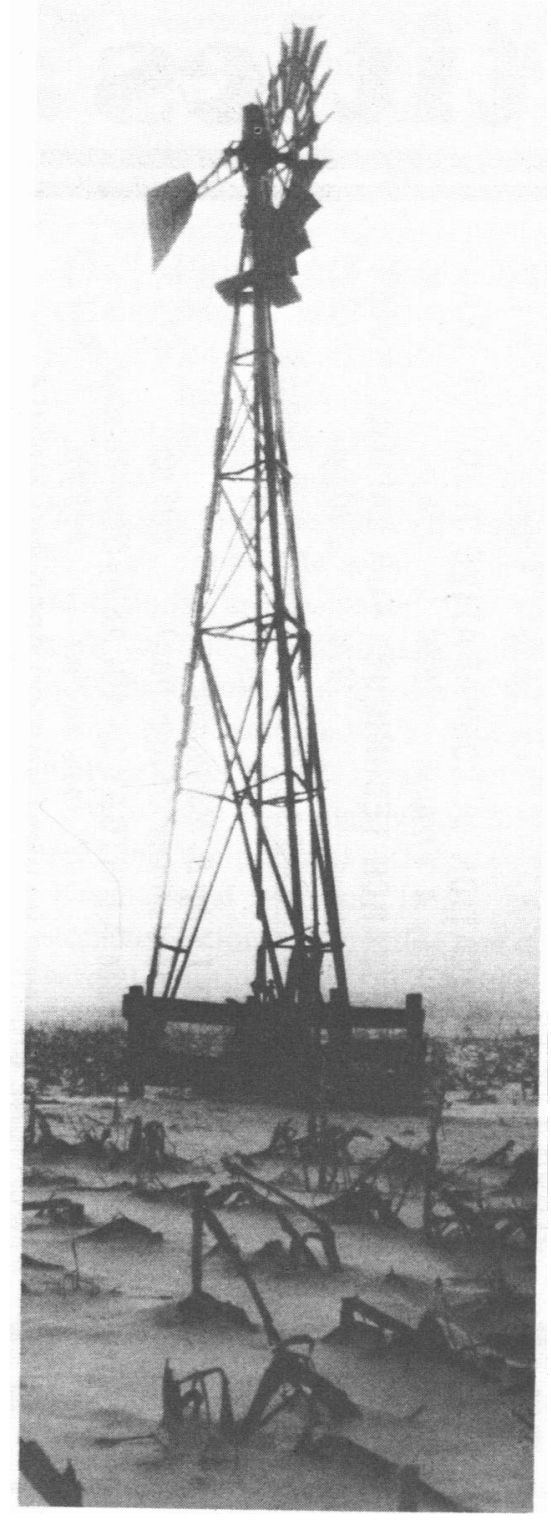

Climate is changing. Parts of our world have been cooling. Rain belts and food-growing areas are shifting. People are starving. And we have been too slow to realize what is happening and why.

In recent years, world climate changes have drawn more attention than at any other time in history. What we once called "crazy weather," just a few years ago, is now beginning to be seen as part of a logical and, in part, predictable pattern, an awesome natural force that we must deal with if man is to avoid disaster of unprecedented proportions.

The current climate shift brought wide public attention first in the late 1960 s and early 1970 s, with the famine-producing droughts south of the Sahara. But it is still not generally recognized that the drought of the Sahel is part of a much broader pattern of climatic irregularities, one that has extended through the Middle East to India, South Asia, and North China. Another part of the same climate shift has struck the midwestern and plains states of the U.S., where recent drought and scattered crop failures have had unnerving effects on a delicate national economy, and in England and France, where the worst drought in memory struck during 1976. During the same years, the worst floods in centuries struck parts of the U.S., the Philippines, and Italy. 
THE ARAB BOYCOTT OF ISRAEL

Economic Aggression and World Reaction DAN S. CHILL.

138 pp. Oct. 1976 LC 76-14431 ISBN 0-275-56810-5 $\$ 14.00$

\section{NORTH KOREA'S FOREIGN RELATIONS}

The Politics of Accommodation, 1945.1975 WAYNE S. KIYOSAKI

154 pp. Oct. 1976 LC 76-19548 ISBN 0-275-23490-8 $\$ 16.50$

\section{THE INTERNATIONAL POLITICS OF} EASTERN EUROPE

Edited by CHARLES GATI

324 pp. Nou. 1976 LC 75-23963 ISBN 0-275-55960-2 \$22.50 PSS Student Edition: ISBN 0.275-89500-9 $\$ 6.95$

\section{SOVIET-ASIAN RELATIONS IN THE 1970s AND BEYOND \\ An Interperceptional Study BHABANI SEN GUPTA}

384 pp. Dec. 1976 LC 76-24368 ISBN 0-275-23740.0 \$25.00

NONSTATE NATIONS IN INTERNATIONAL POLITICS

Comparative System Analyses Edited by JUDY S. BERTELSEN

272 pp. Jan. 1977 LC 75-36404 ISBN 0-275-56320.0 \$20.00

\section{DIMENSIONS OF CHINA'S}

FOREIGN RELATIONS

Edited by CHUN-TU HSÜEH

316 pp. Jan. 1977 LC 76-24354 ISBN 0-275-56780-X $\$ 20.00$

\section{TECHNOLOGY TRANSFER AND}

U.S. FOREIGN POLICY

HENRY R. NAU

348 pp. Oct. 1976 LC 76-2908 ISBN 0-275-56790-7 \$22.50

4 PRAEGER PUBLISHERS

200 Park Avenue, New York, N.Y. 10017

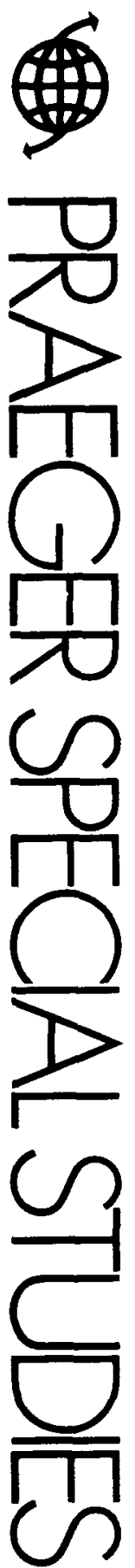




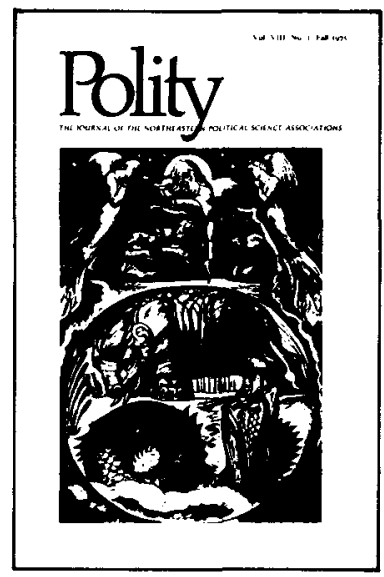

Polity, The Journal of the Northeastern Political Science Association

Recent and forthcoming issues include articles on the parliamentary opposition in Japan; politics, language, and aesthetics; ideology and utopia in Milton Friedman's political economy; a Jungian interpretation of Machiavelli; foreign policy and the politics of interdependence under the Nixon presidency; and other subjects of general interest to political scientists.

\section{Subscription Rates}

NPSA Members (required of all residents of New England, New York, New Jersey, Pennsylvania, and Delaware-includes membership in both the both the state and Northeastern associations): $\$ 10.00$

Other: U.S.A. $\$ 9.00$, Foreign $\$ 9.50$

Student: U.S.A. $\$ 5.00$, Foreign $\$ 5.50$

Subscription order:

Mail to: POLITY, Thompson Hall, University of Massachusetts, Amherst, Massachusetts 01002

Name

Address

Payment enclosed, sum of: 
Along with drought in some places and floods in others, both caused by changing wind patterns, average temperatures of the Northern Hemisphere have been falling. The old-fashioned winters our grandfathers spoke of seem to be returning. The heavy snows of Dickens' time may be returning to England, where the growing season has already been cut by as much as two weeks. The selection of food crop varieties in both North America and Europe are in for sharp reappraisal, in view of the dwindling frost-free agricultural growing season and other climatic changes.

Climate has always had profound effects upon human history, helping both to build and destroy great civilizations. Until now, we have not had the knowledge to react intelligently to the signs of shifting climate. Today, even though we remain essentially powerless to affect climate, we are ready to recognize the signs of change and we are somewhat able to predict the effects of those changes.

This book will help. In these pages, climatologist Reid A. Bryson and science writer Thomas J. Murray present a broad view of climatic change, examining the past in order to view the future.

The prospects are not bright. Bryson, whom Fortune magazine called "the most outspoken perceiver of climatological danger signals" in the United States, says that the world is in "a little ice age," and has been since the sixteenth century, except for a brief respite during the relatively warm years in the middle of the present century. The world climate now seems to be reverting to its normal pattern, he says, and the "crazy weather" we have experienced in recent years is simply an expression of this broad reversal.

Climates of Hunger is a book of paramount importance for our time. It will be essential reading not only for professionals in the field-including agricultural meteorologists, political scientists, geographers, sociologists, and business counselors - but for all who are concerned in any way with environmental trends, world and domestic food supply, and their effects on human institutions.

Reid A. Bryson is one of the world's most astute, productive, and best-known climatologists. $\mathrm{He}$ is the author of three books and more than one hundred forty articles, and the subject of many more. His work has been reported in the New York Times, Fortune, Science, Time, Newsweek, Playboy, the Wall Street Journal, and numerous other national and international publications. He has served as consultant and adviser to many international groups concerned with climate and food production, and is currently a member of the Council of the Smithsonian Institution. Bryson is Professor of Meteorology and Geography at the University of Wisconsin-Madison, and Director of the Institute for Environmental Studies, which he helped to create.

Thomas J. Murray, author of several publications, is a professional science writer who specializes in the presentation of scientific data to nonscientists. He has served with the Institute for Environmental Studies and the College of Engineering at the University of Wisconsin-Madison, and is presently a consultant for the National Academy of Sciences.

June 1977

LC 76-53649 ISBN 0-299-07370-X 224 pages cloth $\$ 8.95$ 


\section{JOURNAL OF PEACE RESEARCH}

an interdisciplinary and international journal edited at the International Peace Research Institute, Oslo in cooperation with an international editorial committee.

Contents of No. 3, 1976:

Marvin S. Soroos: Adding an Intergenerational

Dimension to Conceptions of Peace

Amrut Nakhre: Meanings of Nonviolence: A Study

of Satyagrahi Attitudes

Peter Wallensteen: Interpreting East-West Relations:

Aspects of Post-Cold War Europe

Asbjørn Løvbræk: The Chinese Model of Development

Bjørn Hettne: The Vitality of Gandhian Tradition

Book Notes

Books Received

Annual subscription: Norwegian kroner 75 . - /US $\$ 15.00$

Single issues: Norwegian kroner 20._/US $\$ 4.00$

Editorial correspondence:

The Editor, Journal of Peace Research, Rådhusgt. 4, Oslo 1, Norway

Business correspondence:

Universitetsforlaget, P.O. Box 7508, Skillebekk, Oslo 2, Norway

or:

P.O. Box 142, Boston, Mass., 02113, USA

\section{PARLIAMENTS OF THE WORLD}

\section{A Reference Compendium}

Prepared by Valentine Herman with the collaboration of Francoise Mendel

Edited by Inter-Parliamentary Union

1976. Large-octavo. XII, 985 pages. Bound DM 168,-; $\$ 70.00$

ISBN $311006975 X$

Parliaments of the World is an exhaustive survey of all aspects of the composition, organisation and operation of 56 Parliaments as well as their legislative, budgetary and control functions. It takes the form of a series of 70 tables with country-by-country entries, each table being preceded by explanatory text.

The book contains material gathered during an international enquiry conducted by the International Centre for Parliamentary Documentation, a department of the Inter-Parliamentary Union. Parliaments of the World is deliberately conceived as a compilation of data displayed for each country in turn, avoiding judgements and evaluations.

The result is a reference compendium of lasting interest to scholars as well as to parliamentarians, politicians, journalists and all people involved in the work and life of parliamentary institutions.

$\$$-price is subject to change without further notice. 


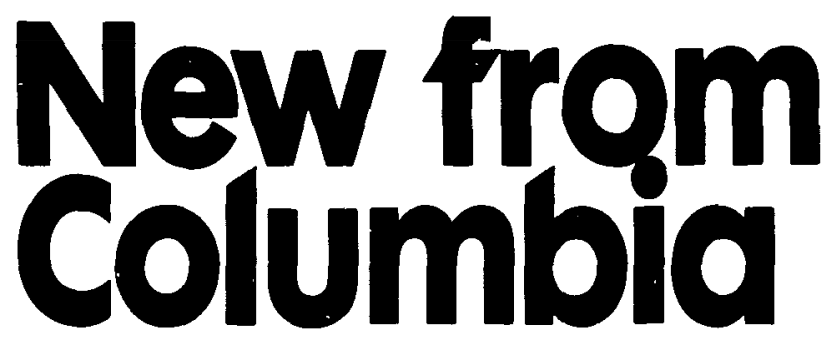

THE POLITICS OF ATTRACTION

Four Middle Powers and the United States ANNETTE BAKER FOX

The relationship between a superpower and friendly middle powers is examined in this unusual study of the mutual attraction and interaction between the United States and four representative middle powers: Canada, Mexico, Australia, and Brazil. Major areas explored include defense, trade, investment, and foreign policy.

Institute of War and Peace Studies

$\$ 15.00$

\section{SHARING THE WORLD'S RESOURCES OSCAR SCHACHTER}

"Oscar Schachter offers an insightful and innovative perspective on the future of the world's diminishing resources. . . This book is well worth reading for all of us who must come to grips with the environmental problems of an ever increasing dependent world economy."

Jacob K. Javits, United States Senate

$\$ 7.95$

\section{DEVELOPING THE ICBM \\ A Study in Bureaucratic Politics EDMUND BEARD}

This Bancroft Award-winning study traces the development of the American intercontinental ballistic missile. Stressing the interrelation of politics, strategy, and weapons choice, the author demonstrates that cultural resistance within the Air Force to the idea of long-range ballistic rockets was at least as important as technological or strategic factors in dictating the weapon's progress.

Institute of War and Peace Studies

$\$ 15.00$

\section{THE POVERTY CURTAIN \\ Choices for the Third World MAHBUB UL HAQ}

The most articulate spokesman of the Third World, Mahbub ul Haq, provides here a graphic picture of two economic worldsone embarrassingly rich and the other desperately poor-separated by what he terms "The Poverty Curtain." Detailing concrete proposals for action by the international community, the book is indispensable to an understanding of the real problems of the Third World. 
Politics and Budgeting in the

World Health Organization

\section{By Francis W. Hoole}

In this study behavioral research techniques culminate in the development of a computer model of the WHO budget process, which is used for a suggestive simulation of the future. "[Hoole's] effort to test propositions through computer simulation is most successful." -Aaron Wildavsky (International Development Research Center, Studies in Development, No. 11)

240 pages, bibl., append., index $\$ \$ 10.00$

\section{By Robert F. Byrnes}

\section{Soviet-}

American

Academic Exchanges, 1958-1975

A uniquely qualified authority on Soviet-American academic exchanges analyzes their character and implications with candor and vigor. Byrnes illuminates the nature of the two competing societies, the issues at stake, and the changing character of international politics. 288 pages paper $\$ 10.00$

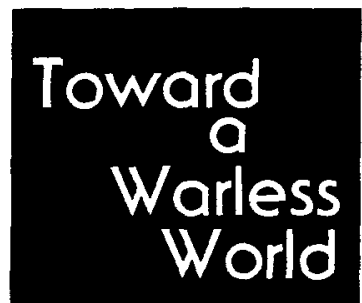

The Travail of the American

Peace Movement, 1887-1914

By David S. Patterson

The full and authoritative story of the generation of American pacifists who were active before the First World War. Developments in the peace movement are related to the emergence of the United States as a major world power.

352 pages, index $\$ 15.00$

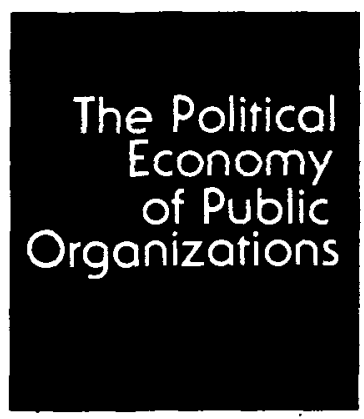

A Critique and Approach to the Study of Public Administration

By Gary L. Wamsley and Mayer N. Zald

"Wamsley and Zald have confronted the paradigm problem in public administration by proposing a framework that links the field's traditional concerns with politics and management to organizational sociology. . . . valuable reading for students of public organization."

-American Political Science Review 128 pages, index (a reprint) paper $\$ 3.50$ 


\section{AMSTERDAM \\ 12th INTERNATIONAL COURSE \\ IN EUROPEAN INTEGRATION \\ Europa Institute-University of Amsterdam \\ 6 September 1977-30 April 1978}

for graduates in law, economics, political science, with separate programmes for each discipline

This Course, conducted in English, provides graduates with a thorough theoretical and practical understanding of the complex problems of European integration.

The academic programmes consist of lectures and seminars on major subjects such as: (law) common market law, doing business in the common market, international legal relations; (economics) economic policies of the EEC, economic and monetary union, external economic relations; (political science) political unification, theory of political integration.

A limited number of scholarships is available. For detailed information, write to the Registrar of the Course: NUFFIC, 27 Molenstraat, the Hague, the Netherlands.

\section{International Problems}

The journal of the Israeli Institute for the Study of International affairs

Carries articles in English, French and Hebrew.

From the contents of issue 3-4(30), 1976:

René Cassin - in memoriam; USSR Proposals to Regulate the Arab-Israeli Conflict - A. Yodfat; On human Rights in the USSR - L. Boim; Zionist "Colonialism" - B. Avishai; Evacuation de(s) Territiores - P. Giniewski; Israeli - Soviet Relations - S. Buthani; The Threat of Palestinian Nuclear Terrorism - L. R. Beres; The Legacy of Palestinian Terrorism - Y. Alexander; The Early Warning System in Sinai - S. Berman; A U.S. Guarantee to Israel? - M. Bruzonsky; West Bank Arab Attitudes on Peace H. Kampf; Inalienable Rights of Israel - G. Schmidt; Israeli Foreign Aid Programs to Africa - V. Belfiglio; Ideologies and International Cooperation - W. Pfeifenberger; The Impact Upon the International Legal System of Internal Changes Within NationStates - M. Mushkat. 


\section{ARTICLES}

Changing configurations of power in North-South relations since 1945 . Tony Smith.

A methodology for design research on interdependence alternatives. Hayward R. Alker, Jr.

Research on research revisited: another half decade of quantitative and field research on international organizations. William J. Dixon.

Underdevelopment, dependence, and integration: the politics of regionalism in the Third World.

W. Andrew Axline.

\section{REVIEW ESSAYS}

Governing the world's money: don't just do something; stand there! Robert W. Russell.

The greening of the globe: a preliminary appraisal of the World Order Models Project (WOMP).

Tom J. Farer.

\section{SYMPOSIUM}

The reform of international institutions: a rebuttal.

C. Fred Bergsten. 